\title{
Factors Affecting Texture Formation of Cu-precipitation Hardening Cold-rolled Steel Sheet
}

\author{
Masaya MORITA, Kaoru SATO ${ }^{1)}$ and Yoshihiro HOSOYA
}

Fukuyama Research Department, Materials and Processing Research Center, NKK Corporation, Kokan-cho, Fukuyama, Hiroshima-ken, 721 Japan. $\quad$ 1) Materials Characterization Department, Applied Technology Research Center, NKK Corporation, Minamiwatarida-cho, Kawasaki-ku, Kawasaki, Kanagawa-ken, 210 Japan.

(Received on May 17, 1993; accepted in final form on October 22, 1993)

.

The mechanism of improving r-value of continuously annealed steel sheets by high temperature hot-coiling in $\mathrm{Cu}$-bearing ultra low $\mathrm{C}$ interstitial-free (IF) steel has been investigated, by using the hot-bands heat-treated at different temperatures from 500 to $800^{\circ} \mathrm{C}$ in order to change the morphology of pre-precipitates in hot-bands. By the ODF analysis of recrystallization texture, it was clarified that the $\gamma$-fiber texture $(\langle 111\rangle / / N D)$ extremely developed by the heat-treatment at the temperature ranging from 720 to $760^{\circ} \mathrm{C}$. TEM observations also revealed that the complex-precipitates composed of Ti-carbosulfide and Cu were observed only in the same range of heat-treating temperature. Improvement of $r$-value by high temperature hot-coiling is caused by the precipitation of $\mathrm{Cu}$ combined with coarse Ti-carbosulfides which avoids the detrimental influence of fine pre-precipitation of $\mathrm{Cu}$ in matrix.

KEY WORDS: extra low carbon steel; interstitial-free (IF) steel; cold-rolled steel sheet; hot-coiling temperature; $\mathrm{Cu}$-precipitation hardening; hot-band microstructure; Ti-carbonitride; Ti-carbosulfide; complex precipitate; r-value; electrical resistivity; recrystallization texture; $\gamma$-fiber texture; $\langle 100\rangle / / N D$-fiber texture; Orientation Distribution Function (ODF); Crystalline orientation distribution function.

\section{Introduction}

Deep drawable high strength steels (HSS) have attracted our attention to applying them into automobile parts from a viewpoint of reducing the weight of car body by gauge down in recent years. So far, it has been considered that the most promising type for panel use was the $\mathrm{Nb}$, Ti-bearing interstitial-free (IF) steel strengthened by alloying the solid-solution hardening elements such as silicon ( $\mathrm{Si})$, manganese $(\mathrm{Mn})$ and phosphorus (P). ${ }^{1-4)}$ In this type of IF-HSS, however, an attainable tensile strength (TS) with the r-value higher than 1.8 has been only up to $440 \mathrm{MPa}$.

As a new type of high formable HSS, on the contrary, Ti-bearing IF-steel with TS of about $600 \mathrm{MPa}$ strengthened by precipitation of $\mathrm{Cu}$ has been introduced by Kishida and Akisue. ${ }^{5)}$ With respect to a hot-coiling condition in that steel, however, they concluded that the hot-coiling temperature of $\mathrm{Cu}$-bearing IF-steel should be lower than $450^{\circ} \mathrm{C}$ to avoid a fine pre-precipitation of $\mathrm{Cu}$ in hot-band which caused a deterioration of r-value, although the high temperature hot-coiling was preferable for improving the r-value of IF-steel due to a perfect pre-precipitation of $\mathrm{C}, \mathrm{N}$ as carbonitride and a coarsening of $(\mathrm{Ti}, \mathrm{Nb})(\mathrm{C}, \mathrm{N})$, TiS and $\mathrm{Ti}_{4} \mathrm{C}_{2} \mathrm{~S}_{2}$ in hot-bands. ${ }^{6)}$ For this state-of-the-art product, we have found out that a high temperature hot-coiling at $720^{\circ} \mathrm{C}$ was preferable for improving $r$-value by an original investigation on optimizing these conflicting conditions in hot-coiling from the viewpoint of avoiding fine $\mathrm{Cu}$-pre-precipitation. ${ }^{7)}$

In this study, by observing the precipitates $((\mathrm{Ti}, \mathrm{Nb})$ $(\mathrm{C}, \mathrm{N})$, TiS, $\mathrm{Ti}_{4} \mathrm{C}_{2} \mathrm{~S}_{2}$ and $\left.\mathrm{Cu}\right)$ in hot-bands and measuring the mechanical properties and recrystallization texture, the mechanism of improving r-value by high temperature hot-coiling in $\mathrm{Cu}$-bearing IF-steel sheet has been investigated.

\section{Experimental Procedure}

The chemical composition of steel used in this study is shown in Table 1. It was smelted by a 50 ton electric furnace and cast into ingots. These ingots were soaked at $1170^{\circ} \mathrm{C}$, hot-rolled into $4.2 \mathrm{~mm}$ thick with a finishing

Table 1. Chemical compositions of steel used. (mass\%)

\begin{tabular}{cccccccccccccccc}
\hline $\mathrm{C}$ & $\mathrm{Si}$ & $\mathrm{Mn}$ & $\mathrm{P}$ & $\mathrm{S}$ & $\mathrm{SolAl}$ & $\mathrm{N}$ & $\mathrm{Cu}$ & $\mathrm{Ni}$ & $\mathrm{Nb}$ & $\mathrm{Ti}$ & $\mathrm{B}$ & & & & \\
\hline 0.0025 & 0.16 & 0.27 & 0.001 & 0.002 & 0.037 & 0.0036 & 1.02 & 0.52 & 0.016 & 0.040 & 0.0004 \\
\hline
\end{tabular}


temperature of $890^{\circ} \mathrm{C}$ and coiled at 450 and $720^{\circ} \mathrm{C}$ to change the size and fraction of pre-precipitates in hot-bands (Hereinafter, the hot-bands coiled at 450 and $720^{\circ} \mathrm{C}$ are referred to as LCT and HCT samples, respectively.). After sampling hot-bands, they were subjected to a laboratory heat-treatment according to the sequence shown in Fig. 1 in order to change the size and morphology of Ti-carbosulfides and $\mathrm{Cu}$-precipitates in hot-bands.

As a first step, only HCT sample was additionally heat-treated at $750^{\circ} \mathrm{C}$ for $1 \mathrm{~h}$ for the purpose of perfect pre-precipitation of $\mathrm{C}, \mathrm{N}$ and the coarsening of $(\mathrm{Ti}, \mathrm{Nb})(\mathrm{C}, \mathrm{N})$, TiS and $\mathrm{Ti}_{4} \mathrm{C}_{2} \mathrm{~S}_{2}$ in hot-bands. As a second step, every sample was re-heated at $850^{\circ} \mathrm{C}$ for $90 \mathrm{~s}$ in order to perfectly dissolve the $\mathrm{Cu}$ into ferrite matrix. Finally, they were re-heated at different temperatures ranging from 640 to $800^{\circ} \mathrm{C}$ for $1 \mathrm{~h}$ followed by furnace-cooling to simulate the hot-coiling which caused the fractional change in $\mathrm{Cu}$-precipitation and the morphological change of Ti-carbosulfide. Another heat-treatment at $500^{\circ} \mathrm{C}$ for $10 \mathrm{~h}$ was carried out to perfectly precipitate the $\mathrm{Cu}$ in ferrite matrix. For each step of heat-treatment, the microstructure of hot-bands was observed by an optical microscope. The morphological changes of precipitates were observed with extraction replicas and electropolished thin foils by using TEM (transmission electron microscope) equipped with a field emission gun. The micro-analyses of precipitates were carried out by TEM-EDS (Energy Dispersive Spectroscopy).

All the hot-bands heat-treated were subjected to grinding from both sides to reduce thickness into $3.8 \mathrm{~mm}$ and cold-rolled to $0.8 \mathrm{~mm}$ thick. These cold-rolled sheets were annealed at $850^{\circ} \mathrm{C}$ for $90 \mathrm{~s}$ followed by air-cooling by using salt-bath to simulate a continuous annealing. Annealed sheets were temper-rolled with a reduction of $0.5 \%$ and subjected to the mechanical testing and the texture analyses. JIS No. 13B specimens $(12.5 \mathrm{~mm}$ in gauge width and $50 \mathrm{~mm}$ in gauge length) were used for measuring r-value which was assessed by $15 \%$ tensile strain for the longitudinal $\left(0^{\circ}\right)$, diagonal $\left(45^{\circ}\right)$ and transverse $\left(90^{\circ}\right)$ directions. Mean r-value $(\bar{r})$ was calculated from the equation of $\bar{r}=1 / 4 \times\left[r\left(0^{\circ}\right)+2 \times r\left(45^{\circ}\right)+r\left(90^{\circ}\right)\right]$. With respect to the recrystallization texture analysis, the orientation distribution functions (ODFs) were calculated by Roe's method ${ }^{8)}$ by using the data from (200), (110) and (211) pole figures measured at the center layer of the specimen. In order to clarify the behavior of $\mathrm{Cu}$-precipitation during heat-treatment of hot-band ranging from 500 to $800^{\circ} \mathrm{C}$, the electrical resistivity was

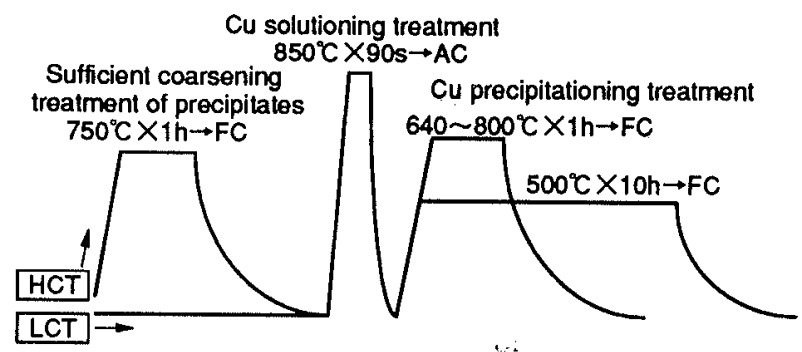

Fig. 1. Sequence of heat-treatment of hot-bands. measured at $-196^{\circ} \mathrm{C}$ by four-terminals method with direct current of $50 \mathrm{~mA}$ by using the specimens which were precisely machined from the LCT sample into $2 \mathrm{~mm}$ square in cross-section and $100 \mathrm{~mm}$ in length.

\section{Results}

\subsection{Changes in Ferrite Structure and Morphology of Precipitates in Hot-bands by Heat-treatment}

Figure 2 shows the ferrite structure of LCT and HCT samples before heat-treatment. Regardless of hot-coiling temperature, ferrite grain size of each sample is almost the same.

Figure 3 shows the microstructural change of hot-bands of LCT sample heat-treated at 500, 720, 760 and $800^{\circ} \mathrm{C}$. Up to about $720^{\circ} \mathrm{C}$, heat-treating temperature hardly affect the ferrite grain structure. However, the coarsening of ferrite grain is observed in the samples heat-treated at higher than $760^{\circ} \mathrm{C}$, and the ferrite structure is perfectly converted into secondary recrystallized grain at $800^{\circ} \mathrm{C}$. The microstructure of $\mathrm{HCT}$ sample showed the same dependency on the heat-treating temperature observed in the LCT sample.

Figure 4 shows the typical precipitates observed in the as- $\mathrm{Cu}$ solution-treated hot-bands of LCT and HCT samples together with EDS spectrum of each precipitates. These precipitates are confirmed to be $\mathrm{Ti}_{4} \mathrm{C}_{2} \mathrm{~S}_{2}$ from the Ti and $\mathrm{S}$ peak-height-ratio in EDS spectrum. The size
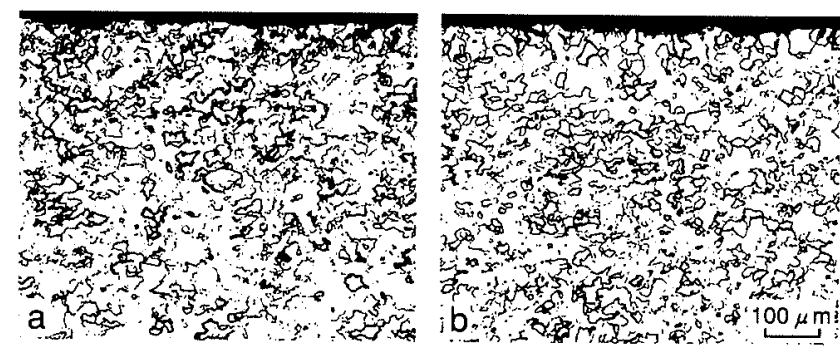

Fig. 2. Optical micrographs of the hot-band's microstructure, (a) LCT sample, (b) HCT sample.
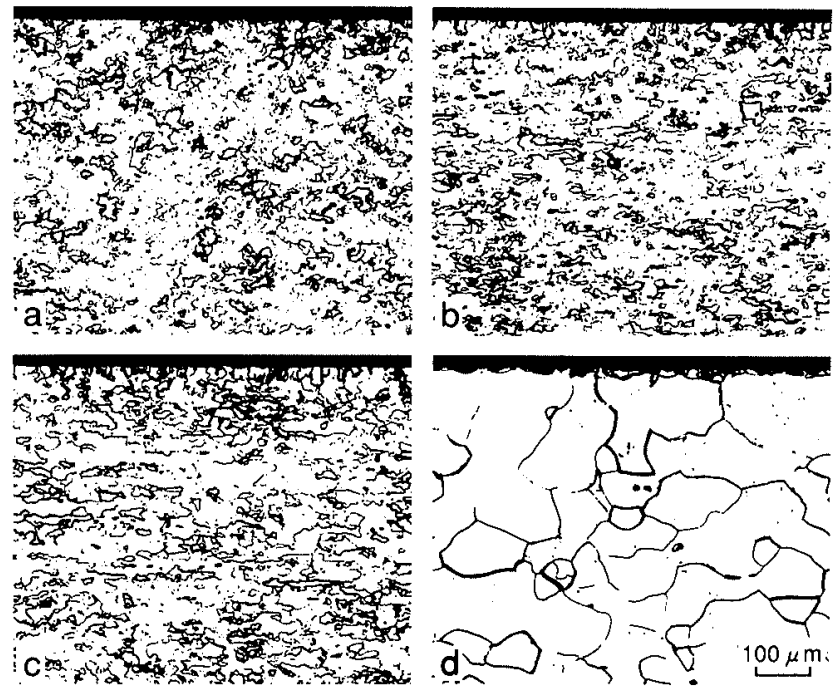

Fig. 3. Optical micrographs of hot-band's microstructure of LCT sample heat-treated by various conditions.

(a) $500^{\circ} \mathrm{C}$ for $10 \mathrm{~h}$, (b) $720^{\circ} \mathrm{C}$ for $1 \mathrm{~h}$, (c) $760^{\circ} \mathrm{C}$ for $1 \mathrm{~h}$, (d) $800^{\circ} \mathrm{C}$ for $1 \mathrm{~h}$. 

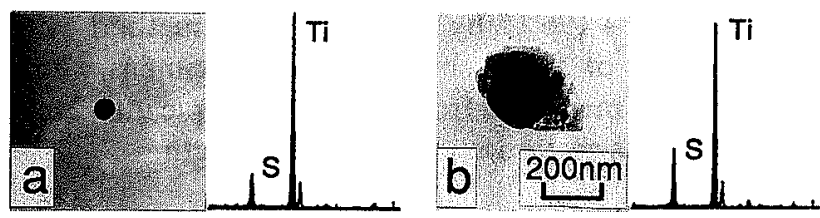

Fig. 4. TEM micrographs and EDS spectra of precipitates observed in hot-bands.

(a) LCT sample, (b) HCT sample.
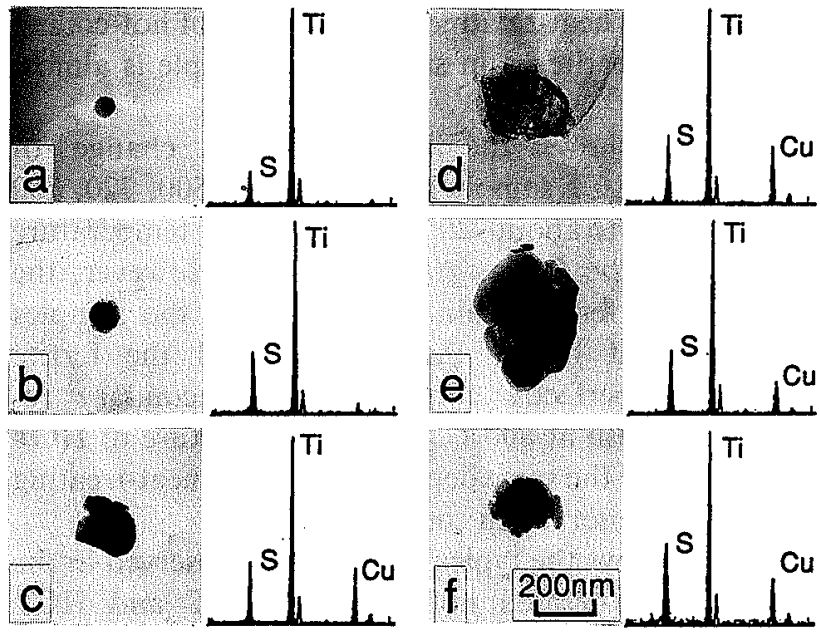

Fig. 5. TEM micrographs and EDS spectra of Ti-carbonitrides observed in hot-bands of LCT sample heattreated by various conditions.

(a) as solution-treated, (b) $500^{\circ} \mathrm{C}$ for $10 \mathrm{~h}$, (c) $640^{\circ} \mathrm{C}$ for $1 \mathrm{~h}$, (d) $720^{\circ} \mathrm{C}$ for $1 \mathrm{~h}$, (e) $760^{\circ} \mathrm{C}$ for $1 \mathrm{~h}$, (f) $800^{\circ} \mathrm{C}$ for $1 \mathrm{~h}$.

of these precipitates in LCT sample is smaller than that in HCT sample. Besides these precipitates, typical TiN precipitates were observed. Since $\mathrm{Cu}$-precipitates was hardly detected in both LCT and HCT samples by not only TEM images but also EDS spectra, $\mathrm{Cu}$ in steels were considered to be perfectly in solid-solution by the solutioning treatment at $850^{\circ} \mathrm{C}$ for $90 \mathrm{~s}$ under the condition of the resolution limit of TEM.

Figure 5 shows the morphological change of precipitates and the EDS spectra observed in LCT samples heat-treated at the temperature ranging from 500 to $800^{\circ} \mathrm{C}$. Compared with the as-Cu solution-treated sample (a), the size of precipitates increased with elevating the heat-treating temperature up to $760^{\circ} \mathrm{C}$. In the sample heat-treated at $800^{\circ} \mathrm{C}$, however, the size of precipitates decreased as compared with that of $760^{\circ} \mathrm{C}$ and another fine precipitates were observed. By EDS analyses, almost all the precipitates were basically composed of $\mathrm{Ti}$ and $\mathrm{S}$, and the complex-precipitation of $\mathrm{Cu}$ was observed in the precipitates heat-treated higher than $640^{\circ} \mathrm{C}$. From the peak-height-ratio of Ti and $\mathrm{S}$, the precipitates observed are presumed to be Ti-carbosulfide. $\mathrm{Cu}$ detected is due to complex-precipitates with Ticarbosulfide which precipitated during heat-treatment.

In order to clarify the constituent of complexprecipitates, EDS analyses were carried out at several points of precipitates in the HCT sample heat-treated at $720^{\circ} \mathrm{C}$. Figure 6 shows the typical precipitates and the results of EDS spectra analyzed at parts of A, B and C.
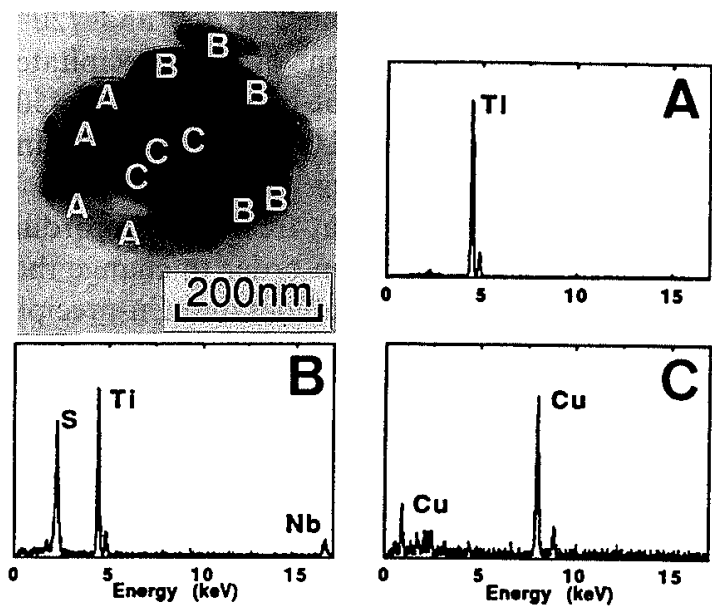

Fig. 6. TEM micrograph and EDS spectra of complexprecipitates observed in hot-band of HCT sample heat-treated at $720^{\circ} \mathrm{C}$.
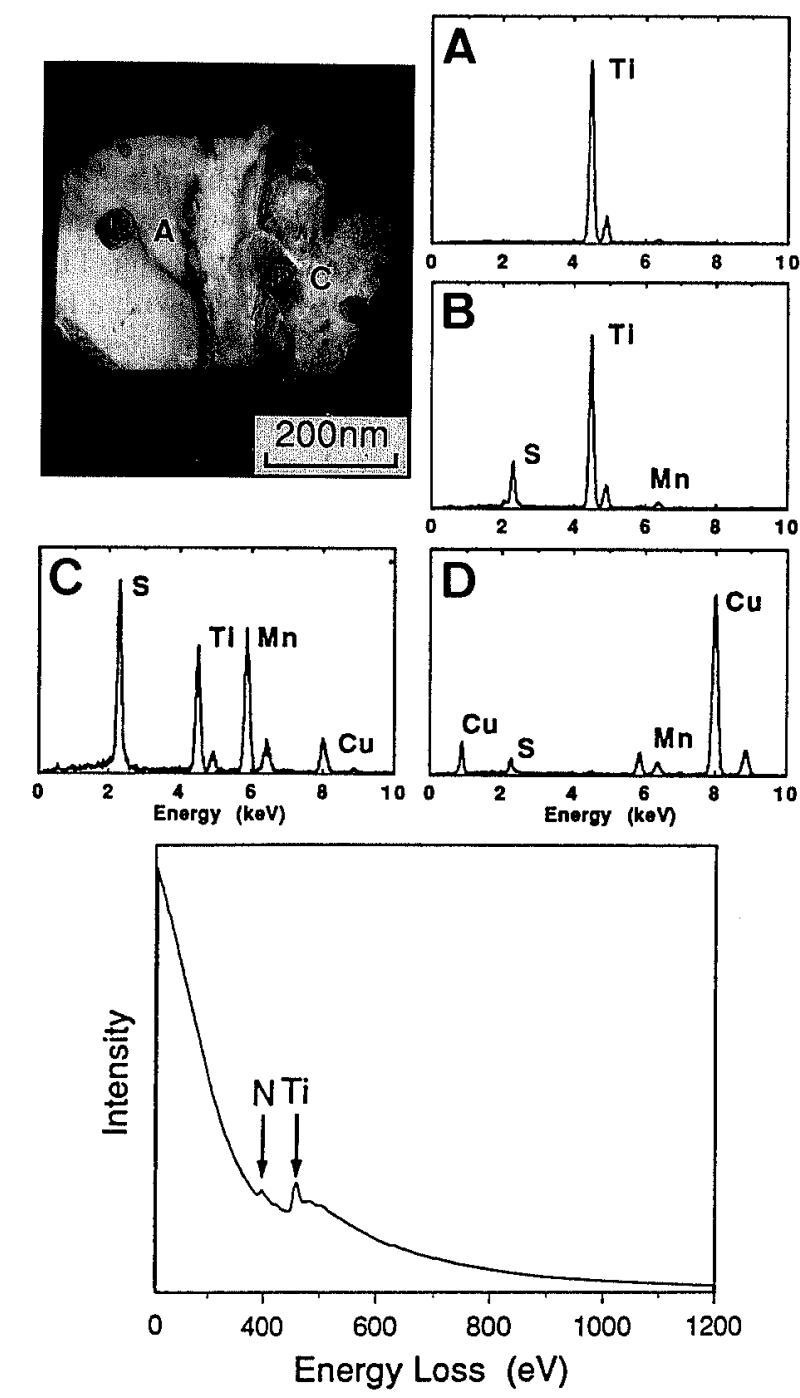

Fig. 7. TEM micrograph and EDS spectra of complexprecipitates observed in hot-band of HCT sample heat-treated at $720^{\circ} \mathrm{C}$ and Electron Energy Loss spectrum detected from part $\mathrm{A}$.

From the EDS analyses, $\mathrm{Ti},(\mathrm{Ti}, \mathrm{S}$ and $\mathrm{Nb}$ ) and $\mathrm{Cu}$ were detected at A, B and C, respectively. Accordingly, part $\mathrm{A}$ in the precipitate is presumed to be Ti-carbonitrides 
and part B is presumed to be Ti-sulfide because of peak-height-ratio of Ti and S. In addition to the above type of precipitates, the complex-precipitates composed of Ti-nitride and $\mathrm{Cu}$ were also observed. Figure 7 shows the TEM image of a typical precipitate and EDS spectra from the points of A, B, C and D indicated in the TEM image. From the part of A, Ti was detected by EDS and $\mathrm{Ti}$ and $\mathrm{N}$ were detected by EELS (Electron Energy Loss Spectroscopy). Mn, S and Ti were detected at points of B and C. Cu was detected from D. Accordingly, this precipitate is considered to be composed of TiN, MnS and $\mathrm{Cu}$.

Figure 8 shows the morphological change of $\mathrm{Cu}$ precipitates in hot-bands of LCT sample heat-treated at 500,640 and $760^{\circ} \mathrm{C}$. Innumerable $\mathrm{Cu}$-precipitates were observed in the samples heat-treated at 500 and $640^{\circ} \mathrm{C}$, the diameter of precipitates was smaller than $20 \mathrm{~nm}$. Although the coarse precipitates of $\mathrm{Cu}$ was observed in the sample heat-treated at $760^{\circ} \mathrm{C}$ as shown in Fig. 8, $\mathrm{Cu}$-precipitates were hardly observed in that heat-treated at $720^{\circ} \mathrm{C}$. The number of Cu-precipitates in HCT sample is somewhat larger than that in LCT samples.

\subsection{Effect of Heat-treating Condition on r-Value and Recrystallization Texture of Annealed Sheets}

Figure 9 shows the change in r-values of annealed

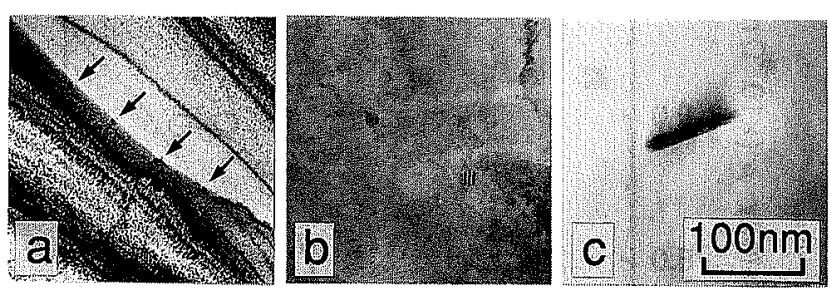

Fig. 8. Cu-precipitates observed in hot-band of LCT sample heat-treated by various conditions.

(a) $500^{\circ} \mathrm{C}$ for $1 \mathrm{~h}$, (b) $640^{\circ} \mathrm{C}$ for $1 \mathrm{~h}$, (c) $760^{\circ} \mathrm{C}$ for $1 \mathrm{~h}$. sheets of LCT and HCT samples as a function of heat-treating temperature. In the case of LCT sample, the $r$-value was improved to about 1.9 with elevating the heat-treating temperature up to $760^{\circ} \mathrm{C}$ and deteriorated by heat-treatment at $800^{\circ} \mathrm{C}$. On the other hand, the $r$-values of HCT samples were sufficiently higher than those of LCT samples because of preliminary coarsening of precipitates. Although the fractional change occurred in $\mathrm{Cu}$-precipitation, the r-value of HCT sample were hardly affected by heat-treating temperatures up to $760^{\circ} \mathrm{C}$. The marked deterioration of $\mathrm{r}$-value occurred at $800^{\circ} \mathrm{C}$ as well as LCT sample. This deterioration of $\mathrm{r}$-value at $800^{\circ} \mathrm{C}$ is caused by the difference in hot-band's ferrite structure, that is, the ferrite grain size in HCT sample is larger than that in LCT sample. Consequently, from the different dependency of the r-value on heat-treating condition between LCT and HCT samples heat-treated at the temperature lower than $720^{\circ} \mathrm{C}$ in which hot-band's structures were sufficiently fine, it is suggested that the size and dispersion of Ti-carbosulfides

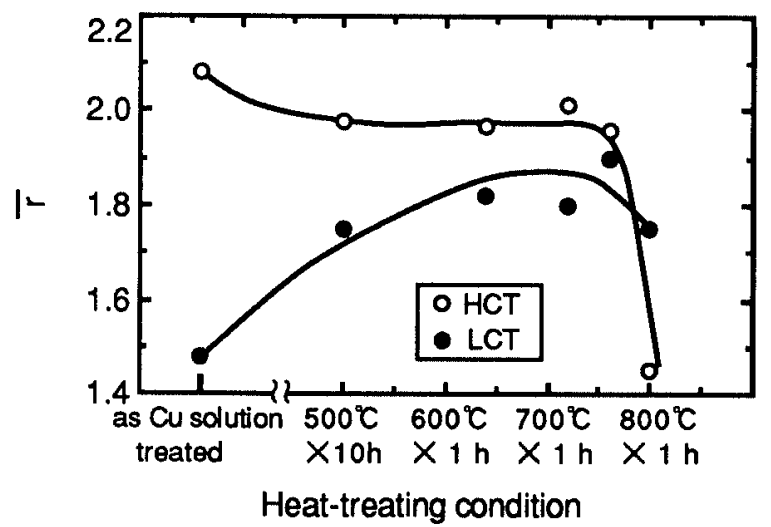

Fig. 9. Effect of heat-treating condition on mean r-value of annealed sheet.
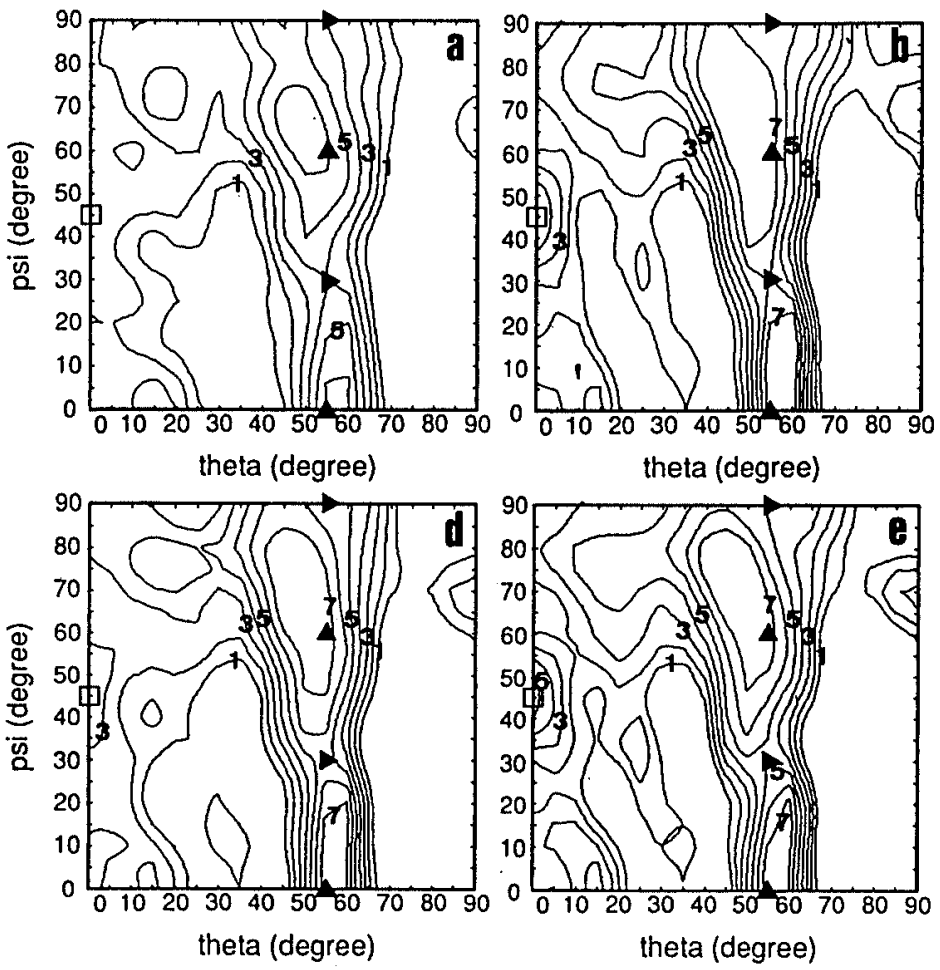
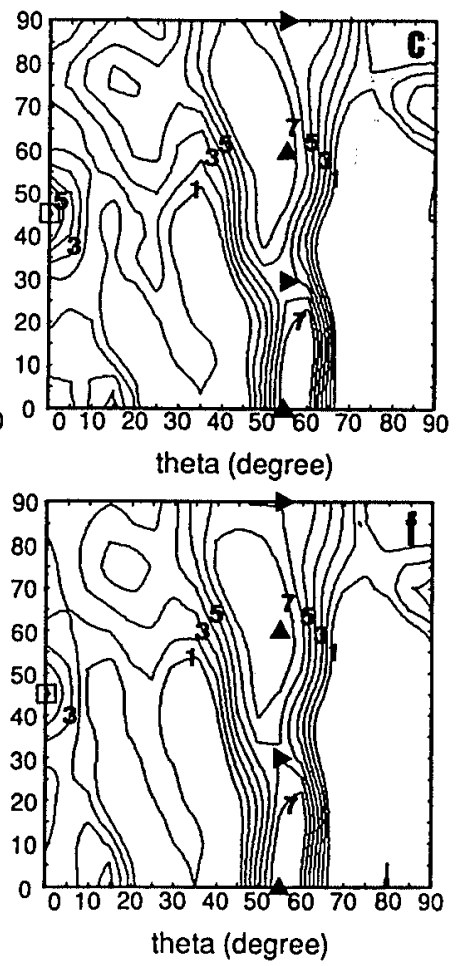

Fig. 10.

Effect of heat-treating temperature of hot-bands on recrystallization texture represented by the $\phi=45^{\circ}$ sections of ODF in LCT sample.

(a) as solution-treated,

(b) $500^{\circ} \mathrm{C}$ for $10 \mathrm{~h}$,

(c) $640^{\circ} \mathrm{C}$ for $1 \mathrm{~h}$,

(d) $720^{\circ} \mathrm{C}$ for $1 \mathrm{~h}$,

(e) $760^{\circ} \mathrm{C}$ for $1 \mathrm{~h}$,

(f) $800^{\circ} \mathrm{C}$ for $1 \mathrm{~h}$

Key; $:\{11\}\langle 011\rangle$,

$\Delta:\{111\}\langle 112\rangle$

$\square:\{100\}\langle 001\rangle$ 

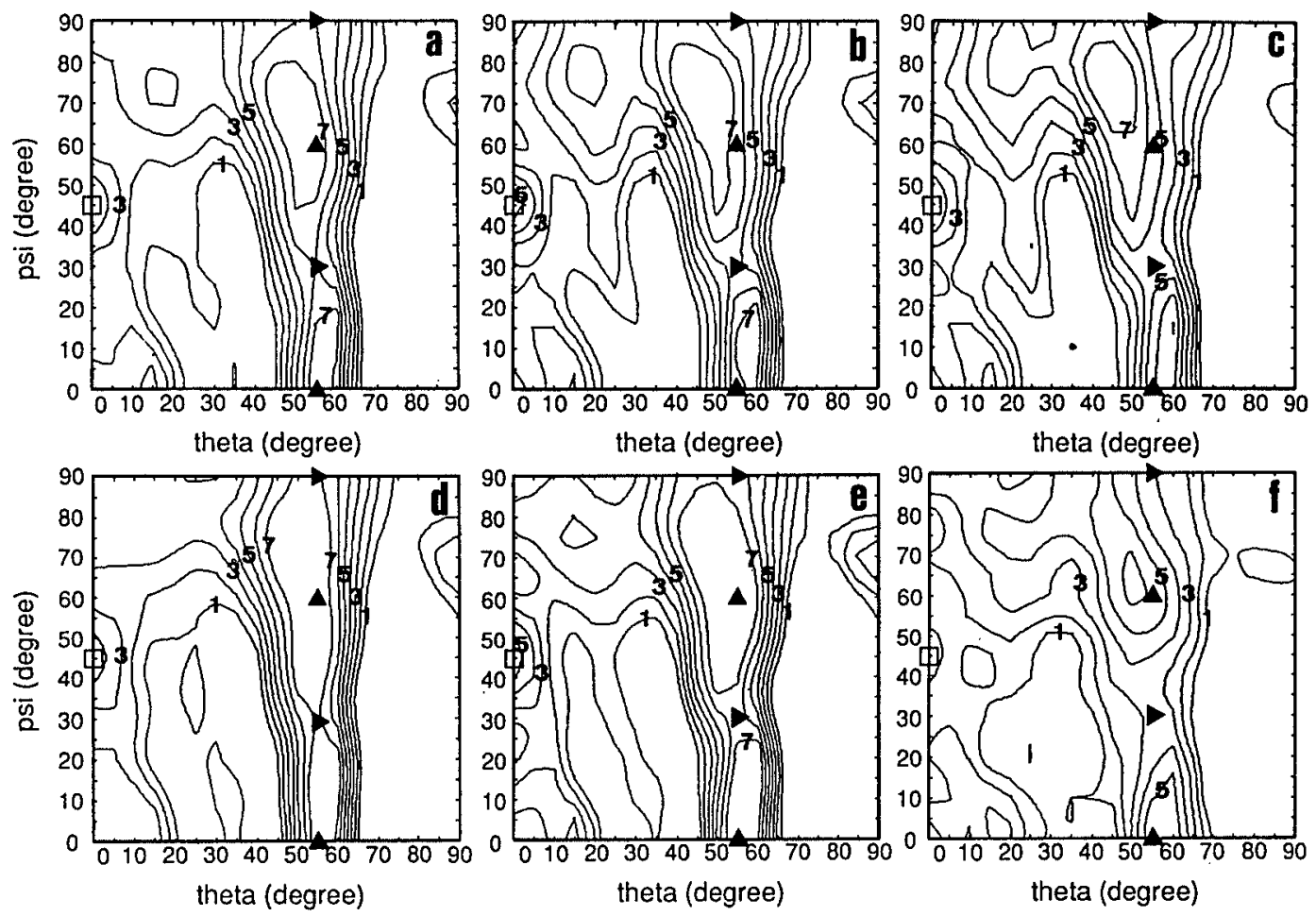

Fig. 11.

Effect of heat-treating temperature of hot-bands on recrystallization texture represented by the $\phi=45^{\circ}$ sections of ODF in HCT sample.

(a) as solution-treated,

(b) $500^{\circ} \mathrm{C}$ for $10 \mathrm{~h}$

(c) $640^{\circ} \mathrm{C}$ for $1 \mathrm{~h}$,

(d) $720^{\circ} \mathrm{C}$ for $1 \mathrm{~h}$,

(e) $760^{\circ} \mathrm{C}$ for $1 \mathrm{~h}$,

(f) $800^{\circ} \mathrm{C}$ for $1 \mathrm{~h}$.

Key; : $\{111\}\langle 011\rangle$,

$\mathbf{A}:\{111\}\langle 112\rangle$,

$\square:\{100\}\langle 001\rangle$.

in hot-band are the most dominant factors to the r-value of $\mathrm{Cu}$-precipitation hardening cold-rolled steel.

The effect of heat-treating condition of hot-bands on the recrystallization texture of annealed sheets of LCT and HCT samples represented by the cross-section of $\phi=45^{\circ}$ in ODFs are shown in Figs. 10 and 11, respectively. In the case of LCT samples, the $\gamma$-fiber texture $(\langle 111\rangle / / \mathrm{ND})$, the density of which is the weakest in the as-Cu solution-treated condition, developed with elevating the heat-treating temperature. This change in the $\gamma$-fiber texture agrees with that of r-value as shown in Fig. 9. With respect to the $\langle 100\rangle / /$ ND-fiber texture, the orientation density of (001)[010] grain $\left(\theta=0^{\circ}\right.$ and $\psi=45^{\circ}$ ) depended on the heat-treating condition. The orientation density of $(001)[0 \overline{1} 0]$ grain is low in the as $-\mathrm{Cu}$ solution-treated condition. In the rest of conditions, however, the (001)[010] texture developed by heattreatment excepting the treatment at $720^{\circ} \mathrm{C}$. In the case of HCT samples, on the other hand, the $\gamma$-fiber texture markedly developed except for the heat-treatment at $800^{\circ} \mathrm{C}$. The grain orientation of $(001)[0 \overline{1} 0]$ was clearly observed in the as- $\mathrm{Cu}$ solution-treated condition. And the density of it was hardly affected by other heat-treating conditions.

\section{Discussion}

\subsection{Behavior of Cu-precipitation during Heat-treatment of Hot-band}

During the heat-treatment of hot-band, the precipitation of $\mathrm{Cu}$ is presumed to be dominated by its solubility in ferrite, precipitation sites and diffusion rate in ferrite. In these factors affecting $\mathrm{Cu}$-precipitation, the solubility limit of $\mathrm{Cu}$ in ferrite is represented by the following equation. ${ }^{9)}$

$$
\log (\operatorname{mass} \% \mathrm{Cu})=4.335-(4499 / T)
$$

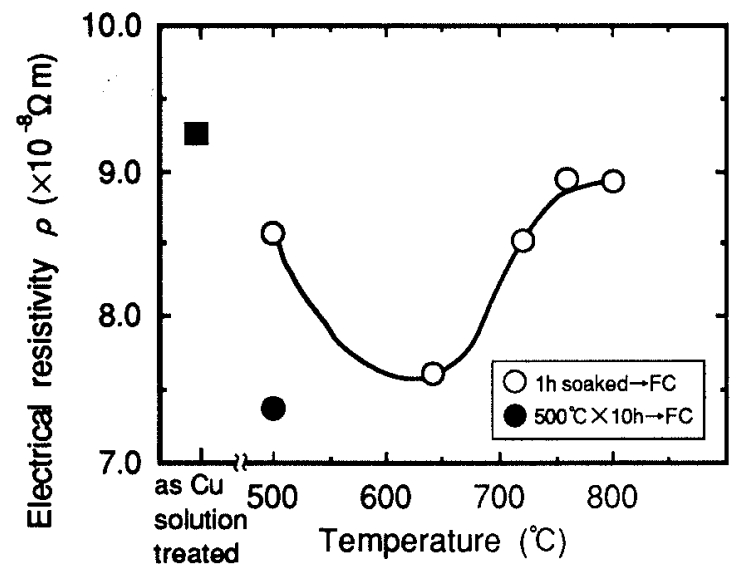

Fig. 12. Change in electrical resistivity by heat-treatment after solution-treatment experimented in LCT sample.

According to the Eq. (1), the solubility limit of $\mathrm{Cu}$ in ferrite changes from 0.03 to $1.39 \%$ during the heat-treatment between 500 and $800^{\circ} \mathrm{C}$. In other words, in the steel used in this study, which contained about $1 \mathrm{mass} \% \mathrm{Cu}$, the condition of $\mathrm{Cu}$ in steel was successively changed from perfect precipitation to perfect solidsolution at the heat-treating temperature from 500 to $800^{\circ} \mathrm{C}$.

With respect to the Ti-carbosulfides, on the other hand, those mean diameter changed from about 50 to $500 \mathrm{~nm}$ as shown in Fig. 5. Regarding the effect of hot-coiling temperature on r-value, Kishida et al. discussed on the basis of the results from two hot-coiling temperatures, i.e. 550 and $780^{\circ} \mathrm{C}$, which were the conditions for perfect precipitation and perfect solid-solution of $\mathrm{Cu}$, respectively. They had not paid attentions to the successive changes in Cu-precipitates and Ti-carbosulfides during heat-treatment up to 800 from $500^{\circ} \mathrm{C}$ in which we observed the morphological change of these precipitates. 
Then, in order to clarify the behavior of $\mathrm{Cu}$ precipitation during heat-treatment of hot-band at the temperature ranging from 500 to $800^{\circ} \mathrm{C}$, the electrical resistivity at $-196^{\circ} \mathrm{C}$ was measured on the LCT samples heat-treated at the same range of temperature.

Figure 12 shows the change in the electrical resistivity $(\rho)$ caused by the different heat-treatment. Under the as- $\mathrm{Cu}$ solution-treated condition, $\rho$ was $9.3 \times 10^{-8} \Omega \mathrm{m}$. The decrement in $\rho$ from this value suggests the quantitative change of $\mathrm{Cu}$-precipitation. In the case of heat-treating for $1 \mathrm{~h}$ at different temperatures from 500 to $800^{\circ} \mathrm{C}, \rho$ became the minimum at $640^{\circ} \mathrm{C}$. The increase in $\rho$ at the heat-treating temperature higher than $640^{\circ} \mathrm{C}$ is caused by both an quantitative increase of the $\mathrm{Cu}$ in solution at heat-treating temperature and an insufficient precipitation of $\mathrm{Cu}$ during furnace-cooling after heattreating.

On the other hand, the increase in $\rho$ at $500^{\circ} \mathrm{C}$ is caused by the marked descent of diffusion rate of $\mathrm{Cu}$ in ferrite at $500^{\circ} \mathrm{C}$, that is to say, according to the results concerning the diffusion of $\mathrm{Cu}$ in ferrite after Lazarev and Golikov, ${ }^{10)}$ the diffusion coefficients of $\mathrm{Cu}$ in ferrite; $D$ at 500 and $640^{\circ} \mathrm{C}$ are $1.2 \times 10^{-20}$ and $4.4 \times 10^{-18} \mathrm{~m}^{2} \mathrm{~s}^{-1}$,

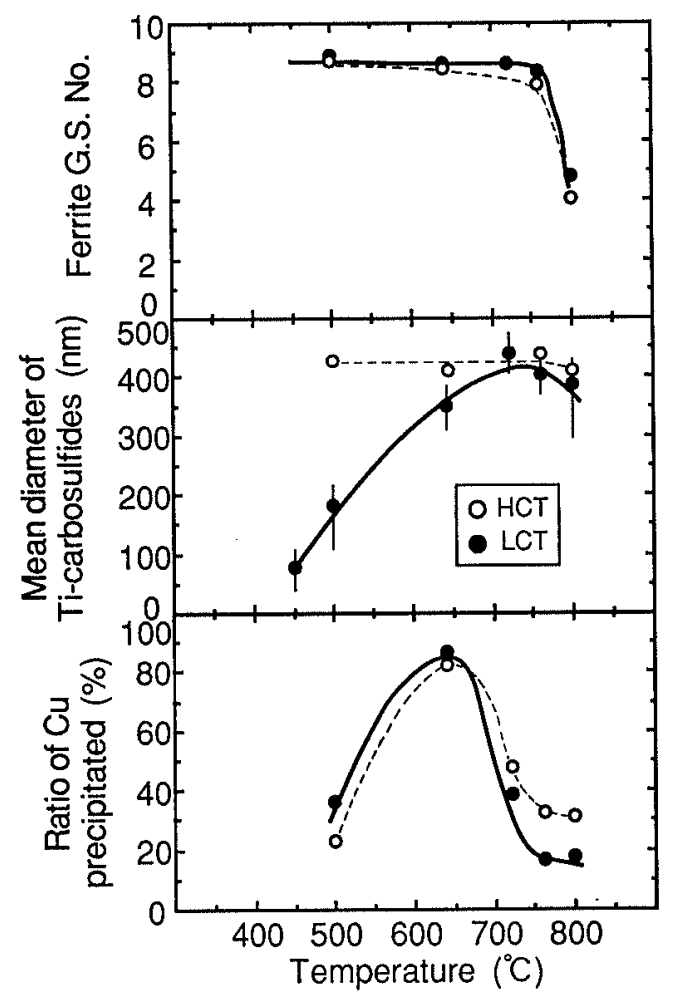

Fig. 13. Change in the dominating factors affecting $r$-value as a function of heat-treating temperature of hot-bands. respectively. Accordingly, the diffusion pass length $\left(\propto 2 \times(D t)^{1 / 2}\right)$ of $\mathrm{Cu}$ in ferrite at $500^{\circ} \mathrm{C}$ is one-19th of that at $640^{\circ} \mathrm{C}$.

Then, in order to confirm the quantitative level of $\rho$ under the perfectly precipitated condition, we measured the electrical resistivity of the specimen heat-treated at $500^{\circ} \mathrm{C}$ for $10 \mathrm{~h}$ according to the results after Hornbogen and Glenn. ${ }^{11)}$ Consequently, $\rho$ of $7.4 \times 10^{-8} \Omega$ m depicted in Fig. 12 gives the quantitative level of $\rho$ under the perfect precipitation of $\mathrm{Cu}$ in this investigation.

\subsection{Effect of Metallurgical Factors Affecting the Formation of Recrystallization Texture}

As indicated above, the ferrite grain size, the morphology and size of Ti-carbosulfides and the fraction of $\mathrm{Cu}$-precipitation separately changed during the heattreatment of hot-band. Figure 13 shows the changes in these metallurgical factors as a function of the heattreating temperature.

Now, we consider the metallurgical factors affecting the formation of recrystallization texture. In order to clarify the each effect of the ferrite grain size of hot-band, the size of Ti-carbosulfides and the fraction of $\mathrm{Cu}$ precipitation on recrystallization texture, the samples of which metallurgical factors independently changed were selected and subjected to the analyses of $\gamma$-fiber and $\langle 100\rangle / /$ ND-fiber textures. Table 2 shows the interrela-

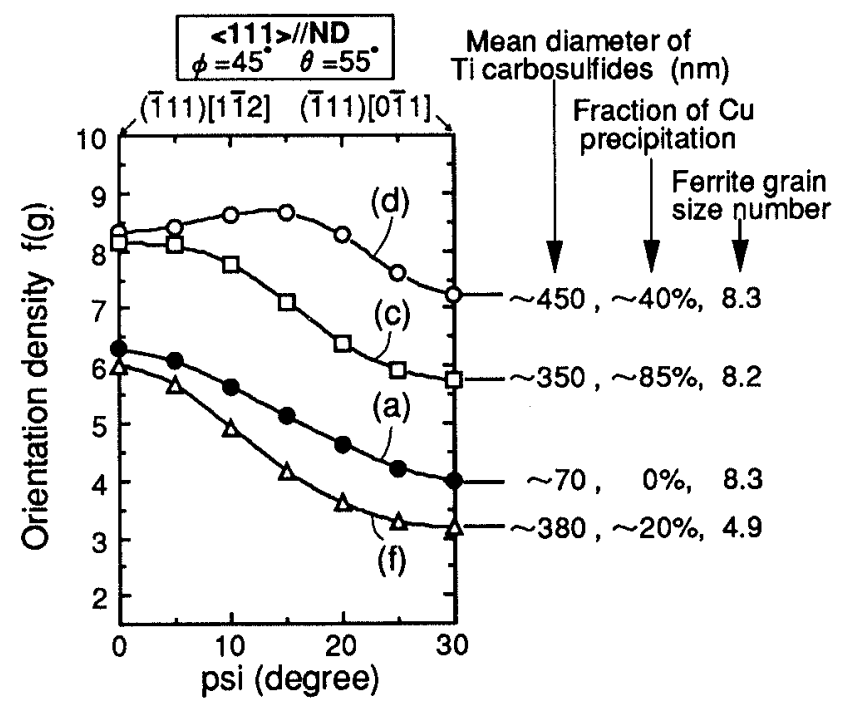

Fig. 14. $y$-fiber texture of (a), (c) shown in Fig. 10 and (d), (f) shown in Fig. 11.

(a) as solution-treated of LCT sample, (c) $640^{\circ} \mathrm{C}$ for $1 \mathrm{~h}$ of LCT sample, (d) $720^{\circ} \mathrm{C}$ for $1 \mathrm{~h}$ of HCT sample, (f) $800^{\circ} \mathrm{C}$ for $1 \mathrm{~h}$ of HCT sample.

Table 2. Interrelation of heat-treating conditions of hot-bands and metallurgical factors in hot-bands.

\begin{tabular}{|c|c|c|c|c|c|c|}
\hline \multirow{2}{*}{$\ldots$} & \multirow{2}{*}{ No. } & \multirow{2}{*}{ Heat-treating condition } & \multirow{2}{*}{ G.S. No. } & \multirow{2}{*}{$\begin{array}{l}\text { Mean diameter } \\
\text { of } \mathrm{Ti}(\mathrm{CS})^{*}\end{array}$} & \multicolumn{2}{|c|}{ Condition of $\mathrm{Cu}$ in matrix } \\
\hline & & & & & In solution & Precipitation \\
\hline \multirow[t]{2}{*}{;in } & 1 & as solution-treated & 8.2 & $70 \mathrm{~nm}$ & Almost all & Few \\
\hline & 2 & $640^{\circ} \mathrm{C} \times 1$ h soaked & 8.3 & $340 \mathrm{~nm}$ & A few $(\sim 10 \%)$ & Fine precipitation (ptt.) \\
\hline \multirow{2}{*}{$s^{*}$} & 3 & $720^{\circ} \mathrm{C} \times 1$ h soaked & 8.3 & $450 \mathrm{~nm}$ & Half $\quad(\sim 60 \%)$ & Coarse ptt. with Ti(CS) \\
\hline & 4 & $800^{\circ} \mathrm{C} \times 1$ h soaked & 4.8 & $380 \mathrm{~nm}$ & Almost all & Coarse ptt. with $\mathrm{Ti}(\mathrm{CS})$ \\
\hline
\end{tabular}

* Ti-carbosulfide. 


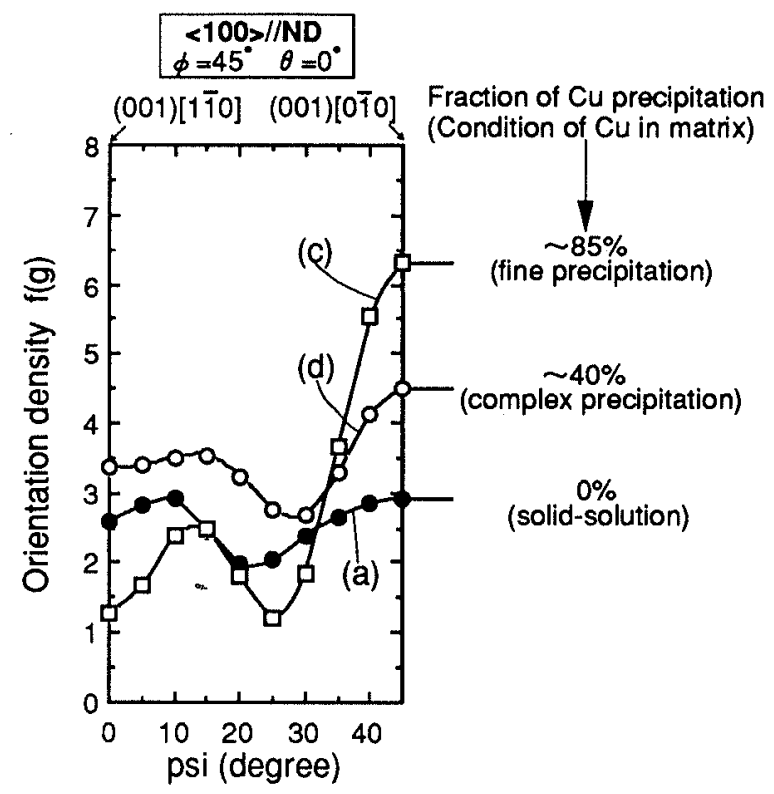

Fig. 15. $\langle 100\rangle / /$ ND-fiber texture of (a), (c) shown in Fig. 10 and (d) shown in Fig. 11.

(a) as solution-treated of LCT sample, (c) $640^{\circ} \mathrm{C}$ for $1 \mathrm{~h}$ of LCT sample, (d) $720^{\circ} \mathrm{C}$ for $1 \mathrm{~h}$ of HCT sample.

tion of heat-treating conditions of hot-bands and metallurgical factors in hot-bands. LCT samples were used for Nos. 1 and 2, and HCT samples were used for Nos. 3 and 4 in Table 2.

\section{(1) Change in $\gamma$-fiber Texture}

Figure 14 shows the effects of metallurgical factors on the $\gamma$-fiber texture. The $\gamma$-fiber texture developed with the growth of Ti-carbosulfides in hot-band which was realized by high temperature hot-coiling. In the case of heat-treatment at $800^{\circ} \mathrm{C}$, however, $\gamma$-fiber texture markedly declined despite an existence of coarse Ti-carbosulfides. This marked declination of $\gamma$-fiber texture is caused by a reduction in grain boundary area, which is the nucleation site of $\{111\}\langle 110\rangle$ grain, ${ }^{12)}$ due to a coarsening of ferrite grains. In the samples heattreated at 640 and $720^{\circ} \mathrm{C}$, with respect to the effect of $\mathrm{Cu}$-precipitation on an improvement of $\gamma$-fiber texture, the complex-precipitation with coarse Ti-carbosulfides realized at $720^{\circ} \mathrm{C}$ is preferable to the fine precipitation of $\mathrm{Cu}$ in ferrite at $640^{\circ} \mathrm{C}$.

Accordingly, all the factors investigated are dominant to the development of $\gamma$-fiber texture. Consequently, the hot-coiling at $720^{\circ} \mathrm{C}$ is presumed to be preferable to improve the $\gamma$-fiber texture in the Cu-bearing IF-steel, by realizing fine hot-band's ferrite structure, coarse Ticarbosulfides and little fine $\mathrm{Cu}$-precipitation in ferrite matrix.

\section{(2) Change in $\langle 100\rangle / / \mathrm{ND}$-fiber Texture}

The results concerning the electrical resistivity shown in Fig. 12 revealed that the fraction of Cu-precipitation was the highest under the heat-treating at $640^{\circ} \mathrm{C}$. Then, the ODFs obtained from heat-treatment of Nos. 1 to 3 shown in Table 2, of which metallurgical factors were different in the size of Ti-carbosulfides and the fraction of $\mathrm{Cu}$-precipitation, were subjected to the analyses of $\langle 100\rangle / / \mathrm{ND}$-fiber texture. Figure 15 shows the results of them.

The most distinctive change in the $\langle 100\rangle / /$ ND-fiber texture is the marked development of the (001)[010] texture (on $\psi=45^{\circ}$ ) by heat-treating at $640^{\circ} \mathrm{C}$. The crystalline orientation distribution function; $f(g)$ of (001)[010] grain is reduced under both as- $\mathrm{Cu}$ solutiontreated and heat-treated at $720^{\circ} \mathrm{C}$. These results suggest that the existence of the fine $\mathrm{Cu}$-precipitates in ferrite matrix enhances the development of (001)[010] texture, and the size of Ti-carbosulfides plays little effective roles in the development of $\langle 100\rangle / /$ ND-fiber texture.

Consequently, from the correlation between the metallurgical factors in hot-bands and the recrystallization texture, the coarsening of Ti-carbosulfides, the refining of ferrite grain and the avoidance of fine precipitation of $\mathrm{Cu}$ in ferrite matrix are effective to the development of $\gamma$-fiber texture, and the amount of fine $\mathrm{Cu}$-precipitates in ferrite matrix dominates the development of (001)[010] texture.

\section{Conclusion}

In order to clarify the mechanism of improving $r$-value by high temperature hot-coiling in Cu-bearing IF-steel sheet, the metallurgical factors affecting the formation of recrystallization texture have been studied. Results obtained are summarized as follows:

(1) The mean $\mathrm{r}$-value of the Cu-bearing IF-steel sheet is improved to about 2.0 by the heat-treatment at $720^{\circ} \mathrm{C}$. TEM observations reveal that complex-precipitates composed of Ti-carbosulfide and $\mathrm{Cu}$ are observed only in the same hot-coiling temperature mentioned above.

(2) With respect to the metallurgical factors, the coarsening of Ti-carbosulfides, the refining of ferrite grain and the avoidance of fine precipitation of $\mathrm{Cu}$ in hot-band play the important roles in development of $\gamma$-fiber texture.

(3) Improvement of $\mathrm{r}$-value by high temperature hot-coiling is caused by the development of $\gamma$-fiber texture by precipitation of $\mathrm{Cu}$ combined with coarse $\mathrm{Ti}$ carbosulfides which avoid a fine precipitation of $\mathrm{Cu}$ in matrix.

\section{REFERENCES}

1) N. Takahashi, M. Shibata and Y. Furuno: Tetsu-to-Hagané, 66 (1980), S1127.

2) M. Yamada, Y. Tokunaga and M. Yamamoto: Tetsu-to-Hagané, 73 (1987), 1049.

3) A. Okamoto and N. Mizui: Tetsu-to-Hagané, 76 (1990), 422.

4) Y. Hosoya, T. Urabe, K. Tanikawa, K. Tahara and A. Nishimoto: Proc. Int. Symp. on Interstitial Free Steel Sheet: Processing, Fabrication and Properties, ed. by L. E. Collins and D. L. Baragar, (1991), 107

5) K. Kishida and O. Akisue: Tetsu-to-Hagané, 76 (1990), 759.

6) S. Sanagi, T. Kawano, N. Takahashi, O. Akisue, T. Yamada and M. Oda: CAMP-ISIJ, 3 (1990), 1768.

7) Y. Hosoya, M. Morita, K. Tahara, H. Fukumoto and A. Nishimoto: CAMP-ISIJ, 5 (1992), 1823.

8) R. J. Roe and W. R. Kriegbaum: J. Chem. Phys., 40 (1964), 2608.

9) H. A. Wriedt and L. S. Darken: Trans. Metall. Soc. AIME, 218 (1960), 30.

10) V. A. Lazarev and V. M. Golikov: Fiz. Met. Metalloved., 29 (1970). 154.

11) E. Hornbogen and R. C. Glenn: Trans. Metall. Soc. AIME, 218 (1960), 1064.

12) H. Inagaki: Tetsu-to-Hagané, 52 (1966), 882. 